Pobrane z czasopisma New Horizons in English Studies http://newhorizons.umcs.pl Data: 26/04/2023 03:23:11

New Horizons in English Studies 5/2020

\title{
LITERATURE
}

$\infty$

\author{
Bettina Huber \\ University of Passau, Germany \\ BETTINA.HUBER@UNI-PASSAU.DE \\ HTTP://ORCID.ORG/OOOO-OOO1-5009-6483
}

\section{A Story about Ruin: An Ecofeminist Perspective on Omar El Akkad's American War}

\begin{abstract}
This article analyzes Omar El Akkad's 2017 novel American War from an ecofeminist perspective by examining the intersections between environmental issues, gender, and terrorism. The use of different text genres in the broader context of this fictionalized (self) life narrative will also be the focus of this analysis. As a case study for the overall argumentation, special emphasis will be placed on the depiction of the radicalization of the main character, Sara(t) Chestnut.
\end{abstract}

Keywords: Omar El Akkad, American War, ecofeminist criticism, terrorism

\section{Introduction}

This November, $B B C$ News placed the novel American War, published in 2017 by Egyptian-born journalist and author Omar El Akkad, on a list of the 100 most influential novels. This postapocalyptic novel focuses on "[t]he Second American Civil War [which] took place between the years of 2074 and 2095" and "was fought between the Union and the secessionist states of Mississippi, Alabama, Georgia, and South Carolina" caused by the "Southern resistance to the Sustainable Future Act, a bill prohibiting the use of fossil fuels anywhere in the United States" (El Akkad 2017, 27). The protagonist of the novel, Sara T. Chestnut, later called Sarat Chestnut, is radicalized by her experiences in refugee and detention camps, the indoctrination by rebel leaders, and the deaths of her closest family members. She becomes a 'terrorist' and kills "an estimated 110 million people" (El Akkad 2017, 28) —about ten times the number of 
people killed in this imaginary conflict—by unleashing a virus during the Reunification Celebrations at the end of the war.

The assumed reasons for the war are the effects of climate change and environmental policies focused on limiting access to fossil fuels. In times of "Friday for Future"-marches, wildfires, and governmental climate deals, this novel therewith focuses on a contemporary issue. As this novel is set in the future United States of America, it is, of course, also important to keep in mind the environmental policies of the Trump administration. President Trump announced his intention to leave the Paris Climate Agreement in June 2017 and formally notified the United Nations in November 2019 that the U.S. would withdraw from the agreement (Friedman 2019). The Trump administration does not only actively question and challenge scientific findings on climate change, but also focuses on the renewal and strengthening of fossil fuels. In this context, President Trump signed two executive orders to deregulate the building of gas and oil pipelines in April 2019 (Greshko et. al. 2019). This is all a part of the White House strategy to support these environmentally damaging industries and thereby to pander to a specific group of voters and supporters of the current administration. As a White House website fact sheet states, the administration is " $[\mathrm{u}]$ shering in a New Era of American Energy: President Donald J. Trump has put in place policies that tap into America's incredible energy resources" to unleash "Energy Dominance" (White House 2019).

The rhetoric of this fact sheet and other documents connected to this policy show that the Trump administration still caters to the myth of America as a land of abundance first established in the promotional literature of the $17^{\text {th }}$ century by writers such as John Smith. Simultaneously, the word choice exhibited in these documents also implies a specific U.S. American dominance of the energy world market which does not necessarily reflect actual numbers. According to data provided by the U.S. Energy Information Administration, China was the prime producer of energy - predominantly coal — and Saudi Arabia the prime producer of petroleum in 2017 (U.S. Energy Administration 2017). This kind of aggressive rhetoric and disregard for statistics by the Trump administration can be interpreted as an indirect threat to other major energy producers like Saudi Arabia, Russia, China, and Iran.

In the novel American War, the possible consequences of this kind of political rhetoric and ensuing policies are depicted. Therein, the divisive eloquence and steam-rolling policy decisions of the Democratic party that signed the before-mentioned Sustainable Future Act into law leads to a split in public opinion that appears inconsolable. El Akkad shows this split as the beginning of a new civil war. At the same time, women and the environment are represented as connected, which adds another important layer to this text. By employing the micronarrative of Sara T. Chestnut's life as a personification of this environmental conflict, this war becomes more personal - and gendered. Hence, I want to read this novel using ecofeminist theories and focusing on the intersections between the radicalization of Sarat Chestnut and the depiction of environmental threats in the following part of this article. 


\section{Marginalization and Counternarratives: The Novel's Structure}

Before I can focus on the gendered representation of nature, it is essential to analyze the structure of this novel and consider the importance of discourses on historic events. American War is told from both a fictional autobiographical and fictional biographical point of view. Benjamin, Sarat's nephew, tells not only his own story but also the story of his aunt based on the diaries of Sarat (cf. El Akkad 2017, 411). The last part of this four-part story is told through the perspective of then six-year-old Benjamin. The other three parts show a more fluid focalization, starting with the focus on Sarat's mother, moving toward Sarat's perspective, and continuing with Karina's point of view. Karina is the wife of Sarat's brother and Benjamin's mother. While Sarat is the protagonist of the story, she is only very seldomly used as the main reflector figure, showing a distance to her reasoning and actions. This distance can be seen as connected to the frame story, which is focalized, again, through Benjamin, but this time from a perspective of adulthood; a person reflecting on his and his family's past life. Arguably, it seems that Benjamin, as biographer of Sarat's life story, also took a lot of liberties. By mostly excluding Sarat's perspective from the story, even though the story is based on her diaries that obviously include her personal point of view, he distances himself from the narrative. This is even more emphasized when he burns her diaries at the very end of the novel (El Akkad 2017, 413). I argue that this distance is necessary to allow the implied reader a more objective understanding of Sarat's action. While it is easy to empathize with her reasoning, it is also important to question her actions.

At the same time, Benjamin points out that "[t]here's only one page from Sarat Chestnut's diaries [he] didn't burn. It's the first page of the first book. [He] carr[ies] it in [his] wallet, and every now and then [he] read[s] the opening lines" (El Akkad 2017, 415). This ending of the novel, only followed by the first lines of Sarat's writing repeated in the beginning and the end of the text, shows that the narrative of Sarat's life, and thereby the civil war, is lost. By destroying the personal recollections of one of the most important actors in this war, this marginalized perspective and thereby one of the key counter-narratives to the dominant discourse of this conflict disappears. In the novel, this dominant discourse is represented by the inclusion of fake historical documents, for example, excerpts from autobiographies, newspaper articles, letters, and governmental hearings. While they are turned into the counter-narratives to the ongoing main plot of the text, they actually represent the dominant discourse and the perspective of the winners of this war. At the same time, these documents can be seen as a commentary on historical writings, as they are also written quite some time after the end of the Second Civil War. By including these more traditional and official accounts, Benjamin tries to authenticate a narrative that would otherwise most likely be excluded from the public discourse of this war. But by destroying the original documents, he also eradicates a 'real' and raw account of the conflict that could even be perceived as a threat to the new world order established at the end of the novel. 
But the ending of this novel points to another another motif: the importance of nature. As I have already mentioned, the first sentence of the main story and, according to the narrator, the beginning of Sarat's first diary entry, is also the very last sentence of the novel: "I was happy then" (El Akkad 2017, 413; emphasis original). This cyclic repetition of a key sentiment of the novel, namely that early childhood was the happiest time of Sarat Chestnut's life, is set at the end of the narrative, after Sarat's death, and thereby becomes a representation of the human life circle. This cyclic structure can also be found on a formal level. The story is separated into four different parts, each starting in a different month and year, as well as set in a different space. The main narrative starts in April 2075 and ends in January 2095, spanning the twenty years of the Second Civil War. I argue that this cyclic structure of the different months reminds the reader of the natural cycle of seasons in a year. Thereby, nature becomes a key motif in the context of this novel and the war itself.

By focusing on a female protagonist who is often connected to nature, Benjamin, as the fictional biographer of his aunt, creates another layer to this historical counter-narrative. It is no longer just a narrative representing the perspective of the Southern rebel, but it is also a predominantly female perspective on a war-which itself can be seen as a counter-narrative. Similarly, the focus on anthropogenic climate change can be seen as a marginalized perspective on this conflict, as most other fake historical documents included in this novel focus on the political reasons for this war, not the underlying environmental problems (cf. El Akkad 2017, 27-28, 58, 81-2, 152).

\section{Women and Nature: The Theory}

Ecofeminist Greta Gaard (2010) emphasizes "that how we treat nature and how we treat each other are inseparably linked" (60). Reading American War through the lens of ecofeminism thus challenges dominant binaries such as us versus them, male versus female, and terrorist versus hero. At the same time, patriarchal notions about wars are also challenged. In her seminal work Ecofeminism as Politics, Ariel Salleh (2017) argues "that ecological crisis is the inevitable effect of a eurocentric capitalist patriarchal culture built on the domination of Nature, and domination of Woman 'as nature" (35). In the novel, the depicted society is predominantly driven by free market and capitalist thought as men often decide to fight in a war in order to earn money and not necessarily for ideological reasons (El Akkad 2017, 81-2). The text also creates a society based on traditional patriarchal gender roles. It is established very early on that Martina is a stay-at-home mother who takes care of the home (El Akkad 2017, 16) while her husband Benjamin works as the breadwinner for the family (El Akkad 2017, 19). Nature is vilified in the opening of the main narrative as the Mississippi river is now "the Mississippi Sea. [...] The sea's mouth opened wide over ruined marshland, and every year grew wider, the water picking away at the silt and sand and clay, until the old riverside plantations and plastic factories and marine railways became unstable" (El Akkad 
2017, 11). In this precarious society, Sarat Chestnut turns against traditional gender stereotypes, becomes a self-sufficient female terrorist, fighting in a war, surrounded by male soldiers, and questioning their war strategies. Sarat sees these male soldiers as "boys with guns, fanned out across the border, picking fights with Northerners" (El Akkad 2017, 188). Throughout the narrative, Sarat is presented as a female agent of war and is represented as connected to the environment.

Sarat strongly questions male dominance within the patriarchal society she is a part of. Very early in the narrative, Sarat tries to understand the behavior of her brother Simon who wants to scare her: "she sensed in her brother a kind of insecurity, as though trying to scare her was not some cruel way to pass the time, but a vital means of proving something to himself. She wondered if all boys were like this, their meanness a self-defense" (El Akkad 2017, 24). As a teenager, Sarat has a similar experience with other boys in the refugee camp as well. When a boy loses a watch in the sewage, Sarat is able to use her intelligence to retrieve it. Another boy who witnessed the scene challenges Sarat to step into the sewage and Sarat understands that:

he'd left her with an impossible choice - step into the river of filth or be labeled a coward. Even then, at such a young age, she understood that smile for what it was: a mask atop fear, a balm for the crippling insecurity of childhoods deeply damaged. They were fragile boys who wore it, and their fragility demanded menace. [...] she knew there was no winning this dare. That was the point - for there to be no winning, only different magnitudes of losing. (El Akkad 2017, 127)

Sarat considers these situations - when male characters challenge and try to victimize her-to be representations of male insecurities and signs of weakness. At the same time, she realizes that even though she understands their reasoning, she is unable to leave these situations without engaging in one way or another. Her behavior is detrimental to herself regardless of what she chooses to do as the situations she is put in prevent a positive outcome for herself as a woman. Therefore, she understands early on that her agency is limited, and that she must select the option that mostly corresponds with her own convictions.

In the context of the representation of female characters, Sarat and her twin sister, Dana, are presented as opposites. Already at the beginning of the novel, the protagonist challenges gender expectations. Dana, who throughout the novel is described and also idealized as beautiful, puts on lipstick. Six-year-old Sarat is confused by "the thing her sister had smeared all over her lips. Unlike the river and the bush and the beasts and the birds of the natural world, the lipstick did not interest her; it held no promise of adventure. She knew it only as a prop in her twin sister's ongoing obsession with adulthood" (El Akkad 2017, 15). Sarat shuns societal gender expectations and, thereby, her own culture; she is aligned here with the natural world, not with the artificial. In the same scene, Dana calls Sarat "ugly." Their mother harshly criticizes this behavior and forces Dana to apologize. After this apology, Dana calls Sarat a "beautiful girl" (El 
Akkad 2017, 16), a description repeated by Dana throughout the novel, which is also representative of the changing understanding between the twin sisters. Dana accepts Sarat's stoic and withdrawn personality and sees the beauty of Sarat's rebellion against multiple power structures.

This dichotomic representation of the twins can be found in other instances as well. For the character development of Sarat, the attack on their refugee camp and the twins' opposing reactions is pivotal. While Sarat actively forces Dana to hide in the office buildings of the camp during the attacks, Dana passively follows Sarat's lead and even asks Sarat to stay hidden with her (El Akkad 2017, 199). Dana falls asleep and, after hearing voices outside their hiding place, Sarat decides to be active, to not "die crouching" (El Akkad 2017, 200). Even though she is at first in shock after seeing the dead bodies outside the building and hides amongst the corpses to escape the attackers (El Akkad 2017, 202), she overcomes this fear and violently stabs a soldier (El Akkad 2017, 204). Where Dana is depicted as passive, Sarat is shown as active. This further emphasizes their-gendered - differences as Dana is more and more represented as the stereotypical embodiment of femininity in contrast to Dana who challenges this traditional portrayal of women.

Both girls are also connected to the depiction of the war. Living in a tent in the refugee camp, twelve-year-old Dana tries to engage with popular culture in a way most teenager would: she collects posters, listens to music, and reads fashion magazines (El Akkad 2017, 96). In contrast, "[o]n Sarat's side of the tent there were no posters and few possessions. In a large plastic bowl she kept a potpourri of war seeds-bullet casings and wild-toothed slivers of shrapnel" (El Akkad 2017, 96). The fascination with the ongoing war is here subtly connected to the natural world as well. Sarat becomes aligned with war, while Dana represents the wish for a more peaceful past and future.

This double-coding of Sarat as the representative of both untamed nature and war is used consistently throughout the narrative. During her time in a refugee camp, Sarat and her friend Marcus frequently leave the fenced-in area and enter a kind of no-man's land on the border of the ongoing war: "to Sarat this place was a small paradise - a land teeming with life, away from the human pollution and unmagical monotony of the camp itself' (El Akkad 2017, 121). Here, Sarat is connected to both armed conflict and nature. This stands in contrast to the depiction of other women in the narrative. In other instances, when women are connected to nature, nature is depicted as domesticated. For instance, Karina, the caretaker of Sarat and Dana's wounded brother Simon, tries to grow vegetables, fruits, and flowers that have been eradicated as a consequence of climate change (cf. El Akkad 2017, 218, 223, 326). Nature here is confined to flower beds and green houses, becoming far removed from the wilder and more untamed nature Sarat is connected to. These women can also be seen as representatives of peace and are thereby further contrasted with Sarat.

In the course of the narrative, Sarat becomes more and more connected to both nature and violence. When Sarat, aged seventeen, decides to kill a high-ranking general, she uses her own rifle, a rifle: 
[s]he painted little check marks in red fingernail polish on the black shoulder stock, immortalizing the times when the soul of the gun and the soul of its shooter aligned, even if all that died as a result was a helpless rat. She named her weapon Templestowe, after the first true rebel of the Second Civil War, the girl who'd killed the crooked Union president in Jackson. (El Akkad 2017, 234)

Sarat uses a weapon frequently encoded with masculine stereotypes and applies nail polish, a sign of femininity, thereby subverting the gender implications of this weapon. Additionally, the rifle is named after a female heroized rebel fighter. The gun is encoded with both, male and female, gender markers. Similarly, violence, which throughout the narrative represents men and their insecurities, becomes a weapon of a self-assured and confident woman.

At the same time, Sarat and her weapon, a symbol of her gender-subverting behavior, are connected to untamed nature. To use this weapon effectively, Sarat must learn to be still and patient, to become one with her surroundings and thereby part of nature: "Sarat lay still. There was a residual dampness in her pants from when she'd urinated without moving, and now that dampness cooled and hardened. She felt it in the hairs of her legs, down to where her bare ankles rubbed against the earth" (El Akkad 2017, 235). Sarat and her rifle become one with nature, and the intersections between gender, environment, and war are completed when Sarat buries her rifle after shooting the general in an unmarked place in the ground (El Akkad 2017, 240).

\section{Water: A Symbol for Sarat}

The most dominant symbol for this intersection is water and specifically rivers: "Chestnuts [Sarat's family] had lived at the feet of rivers and walls. Always bounded, always trapped - trapped by movement, trapped by stillness" (El Akkad 2017, 217). This ambiguity symbolizes the problems when nature is encoded into war; Sarat's experiences and her convictions do not allow her to change her course: she, just like the river, is "always bounded, always trapped."

After Sarat killed the general, she undresses and takes a bath in the river:

The river smelled of dirt and algae but it also smelled of her: the stink of a week unwashed; a vinegar effluent that grew in the spaces under her arms and between her legs. She loved her scent, carried it like her own newborn child. Now, with her eyes wide open, she sank deep into the water and gave it to the river. (El Akkad 2017, 241)

She, again, becomes one with nature. As nature, throughout this narrative, is coded as a symbol for war, Sarat is associated with war once more. This oneness is connected to cleanliness here as well, an image that is representative of the Chestnut family who are viewed as special miracles solely because they suffered intense trauma and 
survived. Sarat, nature, and war are related to cleanness and purity in this part of the narrative. Therefore, the war and the shooting of the general in particular are coded as positive actions that purify and cleanse her.

But the river is not only a symbol of calmness and cleanliness; Sarat frequently dreams of or feels like she is drowning (cf. El Akkad 2017, 129, 298). This becomes true when Sarat is tortured by waterboarding during an interrogation in a detention camp (El Akkad 2017, 316). Her active strategy of resistance is silence during this time. While she was able to withstand all other forms of torture, including light and noise torture, waterboarding breaks her. She confesses to anything asked of her in an attempt to escape the feeling of drowning. Water and thereby war become the brutal force that break her silence and mark her as a traitor to her cause. Sarat loses her agency and is reduced to inactivity, to "stillness," after this experience and for the remaining time in the detention center.

When she is released after seven years, Sarat slowly regains her agency. She moves in with her brother and his family and, after overcoming her fear of water, goes swimming with her nephew Benjamin: "The sound of water was like a million invisible mouths all whispering at once. The water was alive; I [Benjamin] knew it because the water was moving. I looked at [Sarat] then, and I saw a thing I'd never seen before. My aunt was laughing" (El Akkad 2017, 370). When Sarat chooses to enter the water willingly, when she engages in the conflict actively, her agency and therefore her convictions return. This final turning point reconnects Sarat to nature and also to war. After this scene, Sarat, given the opportunity by a former supporter and mentor to act on her wish for revenge, decides to unleash a deathly sickness on as many Northerners as possible, killing not only people from the North but nearly eradicating anyone in the South as well. Sarat does not use explosives or firearms to kill; she uses a sickness, a "plague" (El Akkad 2017, 28), to kill millions of people. By using a killing method that is closely linked to nature, Sarat becomes the symbol for an environmental crisis that decimates the population. She and nature become one.

\section{The Problem: Patriarchy and Radicalization}

Additionally, Sarat's actions must be seen in the context of her experiences with Albert, a much older man who starts to exploit Sarat's anger and wish for revenge for his personal gains (cf. El Akkad 2017, 149, 170-171, 194-195). He seems to subtly give Sarat access to the kind of information that facilitates her revengefulness; after the refugee camp is attacked and a lot of people are killed, Sarat is willing to kill for Albert's cause which has also become her cause (El Akkad 2017, 209). Sarat, unaware of Albert's strategy to indoctrinate her, describes him as her "teacher" (El Akkad 2017, 184), and her willingness to sacrifice herself and others for this cause is strongly connected to the radicalization she experiences through her relationship with Albert. As Sarat is always aligned with untamed nature in this narrative, it is important to see this 
relationship in the context of the patriarchal society depicted in this story. Albert, as a representative of the patriarchal system, employs not only a woman, but a woman who is a symbol of nature to further his cause without getting personally involved. $\mathrm{He}$ can be seen as Sarat's puppet master in the early stages of her adulthood. As it has already been established, this is not to argue that Sarat does not have any kind of agency, but Albert's teachings in connection with her personal experiences leave her with no other perspective than to fully commit to violence. From an ecofeminist perspective, Sarat's gender in connection with nature are utilized to support a male cause with detrimental effects to her personal life as well as the lives of others.

The character of Karina, the caregiver and wife of Sarat's brother Simon, functions in opposition to Sarat. While Sarat is visualized and compared to untamed nature, Karina represents, as mentioned above, a kind of domesticated nature. She grows flowers and vegetables that were considered extinct (cf. El Akkad 2017, 223, 332). This allows her to create a very good social standing as an entrepreneur during the final period of the civil war when most fighting has already ended (El Akkad 2017, 325). Salleh (2017) argues that women become "mediators of nature" (145) as "traditionally women's work always involves the mediation of exchanges between nature and culture: sweeping floors, cooking vegetables, washing small bodies and clothes, in other words, putting the dirt back "where it should be" (82). In this context, this position as mediator of nature allows Karina not only to challenge the patriarchal society but also to rebuild civilization in the sense that her abilities help support her family and contribute to the survival of others which earns her respect.

But Karina's position as both the mediator of nature and representation of peace is not sustainable in the society where war has become naturalized. Using Karina as a reflector figure, the narrator explains that:

the misery of war represented the world's only truly universal language. Its native speakers occupied different ends of the world, and the prayers they recited were not the same and the empty superstitions to which they clung so dearly were not the same - and yet they were. War broke them the same way, made them scared and angry and vengeful the same way. In times of peace and good fortune they were nothing alike, but stripped of these things they were kin. The universal slogan of war [...] was simple: If it had been you, you'd have done no different. (El Akkad 2017, 226)

In this context, Sarat's actions of killing millions of people are also, to a degree, naturalized. While she is labelled as a terrorist, her actions are represented as natural and understandable. According to the Cambridge Advanced Learner's Dictionary, the term "terrorist," apart from other, more personal connotations, is defined as "someone who uses violent action, or threats of violent action, for political purposes" ("Terrorist" 2014). American War does not negate the terrible consequences of terrorism but asks us to reevaluate our position in these discourses. As Sarat points out, "[t]errorism, goddamn [...]. That word will work on anybody, won't it?" (El Akkad 2017, 284). 
This problem is further complicated when one realizes that in any war both sides engage in violent actions and harm innocent people: "To Sarat Chestnut, the calculus was simple: the enemy had violated her people, and for that she would violate the enemy. There could be no other way, she knew it. Blood can never be unspilled" (El Ak$\operatorname{kad} 2017,250)$. Sarat takes action when she feels that her family, her people, have been slaughtered without a reason. As Layla, Sarat's former friend, points out at the end of the narrative, "you must understand that in this part of the world, right and wrong ain't about who wins, or who kills who. In this part of the world, right and wrong ain't even about right and wrong. It's about what you do for your own" (El Akkad 2017, 410).

This ambiguity emphasizes the main theme of the novel: the interconnections between different narratives of the same historical events. This complex text focuses on the counter-narrative of a fictious Civil War from the perspective of the defeated rebels. At the same time, it presents a contemporary commentary on the possible outcome of policies which marginalize and disenfranchise specific groups of people. Lastly, this text powerfully reflects on a possible future where anthropogenic climate change is ignored. All these narrative strands are connected in the micronarrative of the protagonist and her connection to nature. While Sarat is often able to cross traditional gender stereotypes and to overcome rigid binaries, she is turned into a nearly mythical character in the context of the narrative as her story is presented as a historical reflection that is temporarily removed of the actual events. Her mythos is enhanced by her apparent connection to nature and natural catastrophes, by her actions to start a deadly pandemic. Sarat's personal journey of revenge can be seen as a cautionary tale for contemporary audiences. American War is a novel that asks its readers to challenge mainstream discourses and to engage with counter-narratives and the stories of marginalized groups. In light of current political divides and highly inciting news media reports in the Western world, this call to listen to others seems more important than ever. If we do not engage with marginalized groups, we will never be able to overcome the problems we face today, and our story might also become a story about ruin.

\section{References}

El Akkad, Omar. 2017. American War. New York: Vintage Books.

Friedman, Lisa. 2019. “Trump Serves Notice to Quiet Paris Climate Agreement.” The New York Times, November 4.

Gaard, Greta. 2010. "Women, Water, Energy: An Ecofeminist Approach.” In Water Ethics: Foundational Readings for Students and Professionals, ed. Peter G. Brown and Jeremy J. Schmidt, 59-76. Washington: Island Press.

Greshko, Michael, et al. 2019. “A Running List of How President Trump Is Changing Environmental Policy." National Geographic Society, May 3.

Salleh, Ariel. (1997) 2017. Ecofeminism as Politics: Nature, Marx and the Postmodern. 2nd ed. London: Zed Books. 
Pobrane z czasopisma New Horizons in English Studies http://newhorizons.umcs.pl Data: 26/04/2023 03:23:11

“Terrorist." 2014. Cambridge Advanced Learner's Dictionary \& Thesaurus. Accessed February 10, 2020. https://dictionary.cambridge.org/de/worterbuch/englisch/terrorist.

U.S. Energy Information Administration. 2020. "Total Energy Production 2017." Eia.gov. Accessed July 4, 2020. https://www.eia.gov/international/overview/world.

White House. 2019. "President Donald J. Trump Is Unleashing American Energy Dominance." Whitehouse.gov, May 14. 